\title{
Analisa Pengaruh Pemasangan Distributed Generation Terhadap Profil Tegangan Pada Penyulang Abang Karangasem
}

\author{
I Nyoman Cita Artawa ${ }^{1}$, I Wayan Sukerayasa ${ }^{2}$, Ida Ayu Dwi Giriantari ${ }^{3}$
}

\begin{abstract}
One technique to improve the voltage drop is with the installation of Distributed Generation. One of the Distributed Generation technologies in Bali is PLTS Kubu Karangasem which is a small scale electric generator that uses renewable energy, such as air, water, sun, geothermal, sea wave, ocean current, biomass and biogas to generate electrical energy. The electrical power that can be generated of $1 \mathrm{MW}$. Analysis using Load Flow Analysis Voltage Profile, the voltage drop reached $13,23 \%$ when not connected to DG whereas connected to DG $10,85 \%$ of voltage drop found when it was not connected to DG. Operation DG from 7:00 am to 17:00 pm can reduce the voltage drop during the morning at 8:00 amount $2,22 \%$, at 12:00 amount $3,17 \%$ and at $17: 00$ voltage drop amount $1,78 \%$. Installation of DG interconnection on feeder Abang managed to reduce power losses with the amount of $1.023,682 \mathrm{kWh}$ from total power losses that happened before the installation of DG on feeder Abang.
\end{abstract}

Intisari - Salah satu teknik untuk memperbaiki jatuh tegangan adalah dengan pemasangan (DG) Distributed Generation. Salah satu teknologi Distributed Generation yang ada di Bali adalah PLTS Kubu Karangasem merupakan jenis pembangkit listrik dengan skala kecil yang memanfaatkan energy terbarukan untuk menghasilkan energi listrik dengan daya yang dihasilkan 1 MW. Dari hasil analasis menggunakan Load Flow Analysis Voltage Profile diperoleh hasil drop tegangan maksimum saat tidak terhubung DG sebesar $13,23 \%$ dan saat terhubung DG diperoleh drop tegangan sebesar $10,85 \%$. Beroperasinya DG dari pukul 7:00 sampai pukul 17:00 dapat menurunkan drop tegangan saat pagi hari pukul 8:00 sebesar 2,22 \%, saat siang hari pukul 12:00 sebesar 3,17 \% dan pada saat sore hari pukul 17:00 sebesar 1,78 \%. Dengan adanya interkoneksi DG pada Penyulang Abang maka terjadi penurunan rugi-rugi daya sebesar $1.023,682 \mathrm{~kW}$ dari total rugirugi daya yang terjadi sebelum terhubung dengan DG pada Penyulang Abang

Kata Kunci - Distributed Generation, Profil Tegangan, RugiRugi Daya, Load Flow Analysis, EDSA 2000

${ }^{1}$ Mahasiswa, Jurusan Teknik Elektro dan Komputer Fakultas Teknik Universitas Udayana, Jl. Bay Pas Ngurah Rai No.210 Kelan (tlp:081933049079;e-mail: artawanyomancita@gmail.com)

2, 3 Staf pengajar,Jurusan Teknik Elektro dan Komputer Fakultas Teknik Universitas Udayana, Jalan Kampus Bukit Jimbaran 80361 INDONESIA (telp: 0361-703315; e-mail: sukerayasa@unud.ac.id,dayu.giriantari@unud.ac.id

\section{PENDAHULUAN}

Energi listrik merupakan salah satu energi yang sangat dibutuhkan oleh semua golongan masyarakat untuk menunjang aktivitas dan kegiatan sehari-hari. Pembangkit listrik konvensional pada umumnya didesain dalam skala besar, terpusat, dan dibangun jauh dari pusat beban sehingga membutuhkan jaringan transmisi dan distribusi untuk menyalurkan tenaga listrik. Pertimbangan ekonomi dan lingkungan mengakibatkan fasilitas pembangkitan biasanya diletakkan di daerah pinggiran yang jauh dari pusat beban. Jarak yang cukup jauh akan menyebabkan pengurangan daya, karena dalam pengiriman daya dari pembangkit hingga konsumen terjadi penurunan tegangan dan rugi-rugi daya. [1] [2] [3]

Teknologi Distributed Generation (DG) merupakan pengembangan teknologi sistem tenaga listrik dengan skala kecil yang mengutamakan pemanfaatan sumber-sumber energi terbarukan (renewable energy) yang ramah lingkungan, berkelanjutan (sustainable), dan ekonomis seperti angina, air, laut, biomassa, dan biogas untuk mengahsilkan energy listrik dengan kisaran daya yang dihasilkan antara $1 \mathrm{~kW}-10 \mathrm{MW}$. [4]

Interkoneksi distributed generation ke dalam jaringan distribusi memiliki pengaruh yang signifikan terhadap peningkatan kualitas jaringan dsitribusi tenaga listrik yang meliputi: aliran daya, perbaikan profil tegangan, peningkatan keandalan, dan penurunan rugi-rugi daya. Sebagaian besar jaringan distribusi tenaga listrik dirancang sedemikian rupa sehingga aliran daya mengalir dalam satu arah. Penerapan distributed generation memberikan sumber energy tambahan pada suatu jaringan distribusi tenaga listrik. [2]

PLTS Kubu Karangasem memiliki daya mampu sebesar 1MW dan langsung terinterkoneksi (terhubung) pada system jaringan penyulang Abang. Seluruh daya listrik yang dibangkitkan oleh PLTS ini langsung disalurkan pada system jaringan penyulang Abang tanpa adanya baterai untuk menyimpan energy listrik (esdm.go.id). Pada penelitian ini menganalisis pengaruh pemasangan Distributed Generation terhadap profil tegangan dan rugi-rugi daya pada penyulang Abang sebelum dan sesudah pemasangan DG dengan Load Flow Analysis Voltage Profile. 


\section{DISTRIBUTED GENERATION}

\section{A. Distributed Generation}

Distributed Generation (DG) atau yang dikenal dengan pembangkitan skala kecil tersebar merupakan pemasangan unit pembangkit pada jaringan distribusi. Pembangkitan skala kecil tersebar dapat mereduksi kebutuhan jaringan dalam skala besar walaupun terjadi perubahan pada jaringan sistem tenaga listrik. Teknologi DG sangat diperlukan di sisi jaringan distribusi karena sistem tersebut dapat mengurangi rugi daya pada sistem dan memperbaiki kualitas tegangan untuk terciptanya kehandalan sistem tenaga listrik. Penggunaan DG dapat juga memperbaiki efisiensi, sehingga dapat mempengaruhi performa dari pusat tenaga listrik. [6] [7]

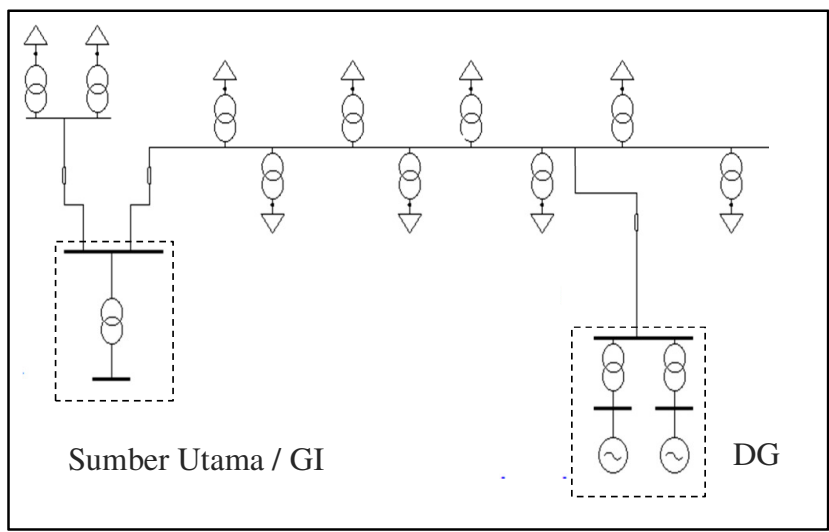

Gambar 1. Interkoneksi DG pada Jaringan Distribusi Tenaga Listrik

DG memiliki fungsi utama yaitu sebagai unit yang difungsikan untuk mengantisipasi apabila terjadi pemutusan dari suplai daya grid atau stand by unit dan difungsikan sebagai unit dipasang pada jam-jam beban puncak atau peaking unit. Karakteristik DG adalah skala kecil, terdistribusi dan dekat dengan pusat beban (closed to load), terinterkoneksi dengan sistem distribusi, membatasi pembangunan jaringan transmisi dan memiliki aliran daya satu arah. Pembangkit ini ramah lingkungan, andal dalam merespon perubahan beban, mengurangi penggunaan bahan bakar fosil, deregulasi dalam pasar kelistrikan dan sejumlah keuntungan lainnya. [7] [8]

\section{B. PLTS Kubu Karangasem}

Data daya yang dihasilkan PLTS yang telah dikumpulkan adalah pada bulan September \& Oktober 2013, dimana data yang diambil adalah data daya yang dihasilkan tiap jam dari pukul 06:00 - 18:00 untuk setiap harinya dari tanggal 1 - 30 (September) dan tanggal 1 - 31 (Oktober). Dari data-data tersebut kemudian dirata-ratakan. Hasil dari daya PLTS dapat dilihat pada gambar 2 dibawah ini. [6]

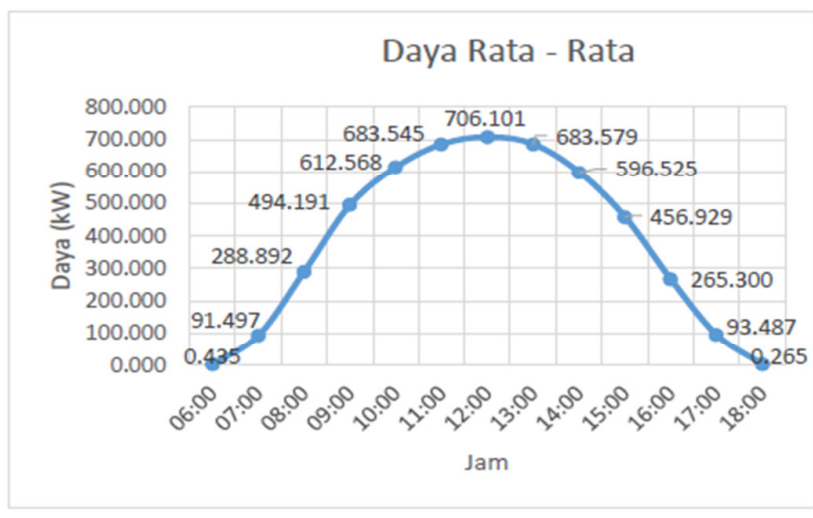

Gambar 2. Grafik Daya PLTS Kubu Karangasem

Dapat dilihat daya tertinggi yang dihasilkan adalah pada pukul 12:00 dengan $706,101 \mathrm{~kW}$ dan data ini yang akan digunakan dalam simulasi.

\section{Analisa Aliran Daya}

Analisis aliran daya juga sangat diperlukan dalam perencanaan pengembangan system tenaga listrik pada masa yang akan dating. Hal tersebut dapat dikaitkan dengan adanya penambahan beban baru, penambahan pembangkit, hubungan interkoneksi dengan system daya lain, dan hubungan jaringan transmisi baru. Dengan kata lain studi aliran daya sangat penting dilakukan untuk menganalisis kelayakan operasi suatu system dalam keadaan existing bila dibandingkan dengan keadaan / perencanaan system untuk masa yang akan datang. Analisis aliran daya pada saluran system tenaga listrik dapat ditentukan dengan persamaan aliran daya kompleks untuk mengetahui besar rugi-rugi daya pada saluran seperti berikut : [9]

$\mathrm{P}_{\mathrm{pq}}+\mathrm{JQ}_{\mathrm{pq}}=\mathrm{V}_{\mathrm{p}} \mathrm{I}_{\mathrm{pq}}$

Arus yang mengalir pada bus kirim (p) dari suatu saluran $\mathrm{p}$ ke q adalah :

$I p q=(V p-V q) Y p q+V p \frac{V^{1} p q}{2}$

Jadi daya yang mengalir dari bus $\mathrm{q}$ ke bus $\mathrm{p}$ adalah

$\mathrm{S}_{\mathrm{qp}}=\mathrm{P}_{\mathrm{qp}}+\mathrm{JQ}_{\mathrm{qp}}=\mathrm{V}_{\mathrm{q}} \mathrm{I}_{\mathrm{qp}}$

Dari persamaan-persamaan tersebut dapat diketahui untuk rugi daya pada saluran $\mathrm{p}-\mathrm{q}\left(\mathrm{SL}_{\mathrm{pq}}\right)$ menjadi :

$\mathrm{SL}_{\mathrm{pq}}=\mathrm{S}_{\mathrm{pq}}+\mathrm{S}_{\mathrm{qp}}$

\section{Aliran Daya Newton Raphon}

Pada Metode Newton Raphson, slack bus diabaikan dari perhitungan iterasi untuk menentukan tegangan-tegangan, karena besar dan sudut tegangan pada slack bus telah ditentukan. Sedangkan pada generator bus, daya aktif dan 
magnitude tegangan bernilai tetap, sehingga hanya daya reakti yang dihitung pada setiap iterasinya. Dalam analisis aliran daya, ada dua persamaan yang harus diselesaikan pada tiaptiap bus. Dalam penyelesaian iterasi pada metode Newton Raphson, nilai dari daya aktif (Pp) dan daya reaktif (Qp) yang telah dihitung harus dibandingkan dengan nilai yang ditetapkan, dengan persamaan sebagai berikut:

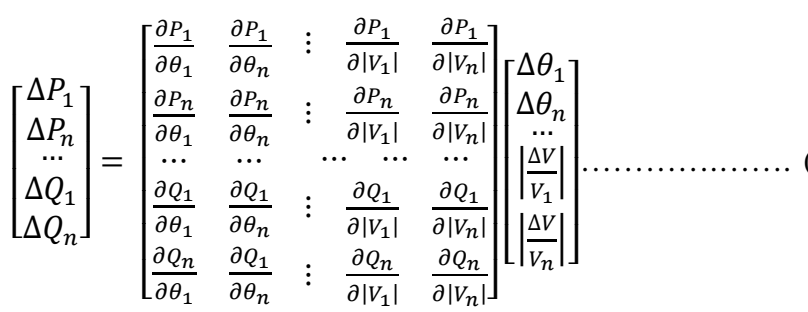

Proses iterasi ini akan berlangsung sampai perubahan daya aktif $\left(\Delta \mathrm{P}_{\mathrm{p}}\right)$ dan perubahan daya reaktif $\left(\Delta \mathrm{Q}_{\mathrm{p}}\right)$ tersebut telah mencapai nilai konvergen $(\varepsilon)$ yang telah ditetapkan. Pada umumnya nilai konvergen antara 0,01 sampai 0,0001 . Matrik Jacobian terdiri dari turunan parsial dari $\mathrm{P}$ dan $\mathrm{Q}$ terhadap masing-masing variabel, besar dan sudut fasa tegangan. Besar dan sudut fasa tegangan yang diasumsikan serta daya aktif dan daya reaktif yang dihitung digunakan untuk mendapatkan elemen-elemen Jacobian. Setelah itu akan diperoleh harga dari perubahan besar tegangan, $\frac{\Delta|V|}{|V|}$, dan perubahan sudut fasa tegangan, $\Delta \delta$. Secara umum persamaan tersebut dapat ditulis sebagai berikut :

$\left|\begin{array}{cc}H & N \\ J & L\end{array}\right|\left|\frac{\Delta \theta}{V}\right|=\left|\begin{array}{c}\Delta P \\ \Delta Q\end{array}\right|$

$\Delta \mathrm{P}$ dan $\Delta \mathrm{Q}$ merupakan selisih daya (power mismatch) antara daya pembebanan yang telah diketahui dengan daya yang diperoleh dari hasil perhitungan. Persamaan untuk daya yang dihitung adalah:

$P_{p}=\left|V_{p}\right|\left[\sum_{q=1}^{n}\left(G_{p q} \operatorname{Cos} \theta_{p q}+B_{p q} \operatorname{Sin} \theta_{p q}\right)\left|V_{q}\right|\right]$

$Q_{p}=\left|V_{p}\right|\left[\sum_{q=1}^{n}\left(G_{p q} \operatorname{Sin} \theta_{p q}+B_{p q} \operatorname{Cos} \theta_{p q}\right)\left|V_{q}\right|\right]$

Sehingga selisih daya (power mismatch) yang terjadi adalah:

$$
\begin{aligned}
& \Delta P_{p}=P_{p}^{\text {Spec }}-\left|V_{p}\right|\left[\sum_{q=1}^{n}\left(G_{p q} \operatorname{Cos} \theta_{p q}+B_{p q} \operatorname{Sin} \theta_{p q}\right)\left|V_{q}\right|\right] . \\
& \Delta Q_{p}=Q_{p}^{\text {Spec }}-\left|V_{p}\right|\left[\sum _ { q = 1 } ^ { n } \left(G_{p q} \operatorname{Sin} \theta_{p q}+\right.\right. \\
& \left.\left.B_{p q} \operatorname{Cos} \theta_{p q}\right)\left|V_{q}\right|\right]
\end{aligned}
$$

\section{E. Perbaikan Profil Tegangan}

Mengatasi jatuh tegangan di sisi pelanggan (sisi tegangan rendah trafo distribusi) agar memenuhi kriteria yang dijinkan, dapat dilakukan dengan cara sebagai berikut:

1. Mengatur tegangan kirim GI

2. Mengubah setelan sadapan sisi primer trafo distribusi
3. Mengalihkan sebagian beban ke penyulang yang lain (rekonfigurasi)

4. Mengganti segmen penghantar yang mengakibatkan jatuh tegangan yang besar

5. Memasang kapasitor

6. Memasang Distributed Generation

\section{METODE PENELITIAN}

Penelitian ini dilakukan di PT. PLN (Persero) Distribusi Bali Area Bali Timur. Tahapan penelitian ini adalah perencanaan diagram alur (flow chart) penelitian pengaruh pemasangan Distributed Generation terhadap profil tegangan pada penyulang Abang. Alur analisis penelitian dapat dilihat pada gambar 3.

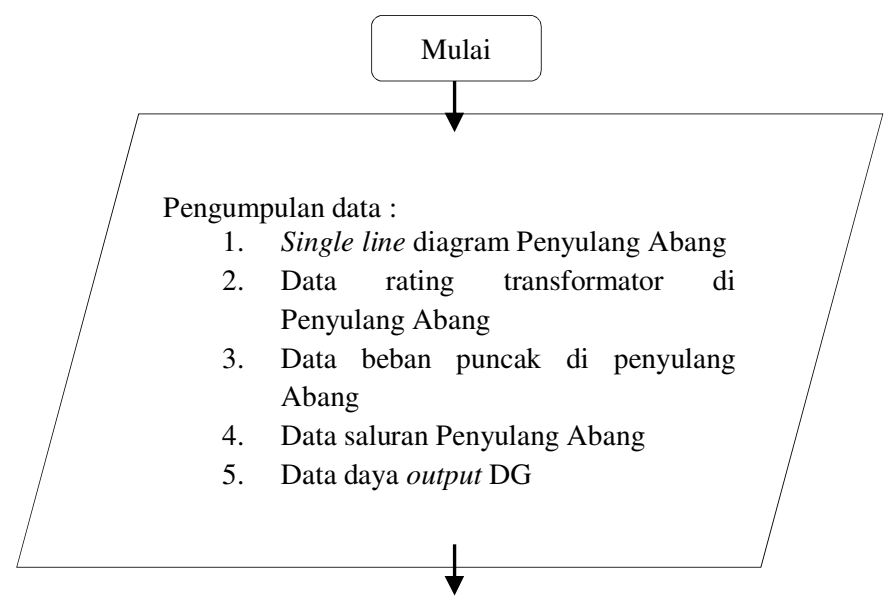

Membuat pemodelan penyulang Abang pada simulator EDSA 2000 dan input data saluran, data transformator serta data beban puncak Penyulang Abang

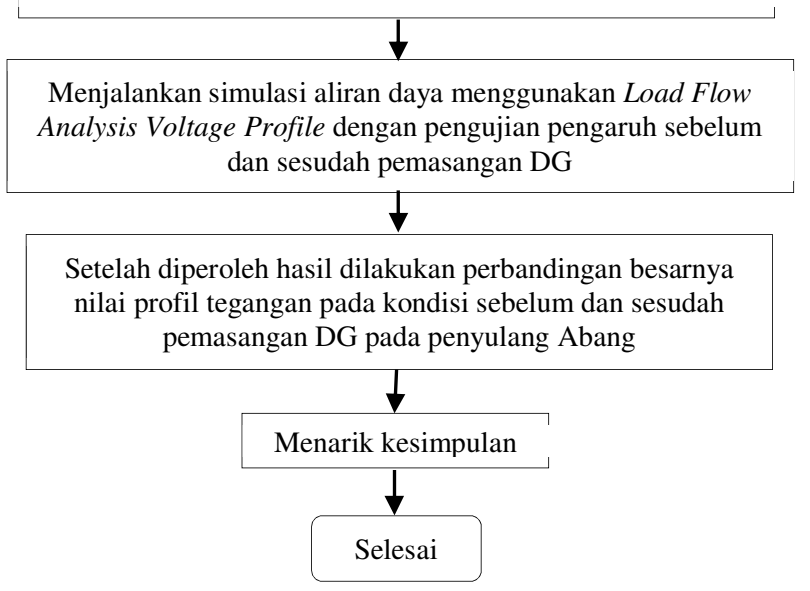

Gambar 3. Alur Analysis Penelitian

\section{A. Single Line Diagram}

Pada penelitian ini menggunakan simulator EDSA 2000 untuk membuat pemodelan penyulang Abang. Single line diagram dapat dilihat pada gambar 4 berikut ini. 


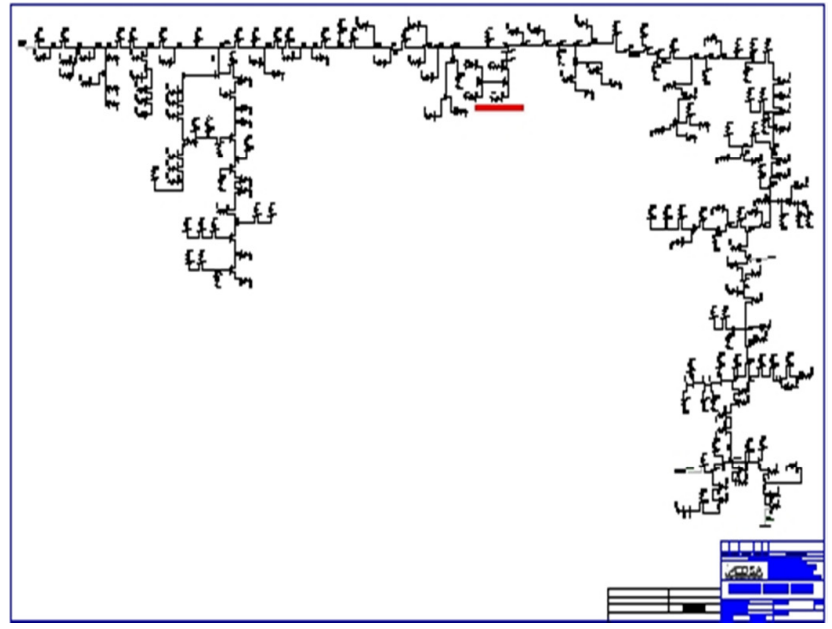

Gambar 4. Pemodelan Penyulang Abang pada Simulator

\section{B. Menganalisis Profil Tegangan}

Analisis profil tegangan dilakukan pada tools load flow analaysis voltage profile dengan pengujian pengaruh sebelum dan sesudah pemasangan DG.

\section{Membandingkan Hasil Simulasi}

Setelah diperoleh hasil simulasi dari load flow analysis voltage profile dilakukan perbandingan hasil profil tegangan sebelum dan sesudah pemasangan DG.

\section{HASIL DAN PEMBAHASAN}

\section{A. Karakteristik Beban Penyulang}

Karakteristik beban penyulang diperlukan untuk mengetahui beban puncak penyulang. Data yang digunakan adalah data selama satu bulan, yaitu dari tiap jam dari pukul 01:00 - 00:00 untuk setiap harinya dan dibuatkan rata-rata per jam. Dalam melakukan penentuan pola pembebanan per trafo berdasarkan beban harian penyulang dapat dilakukan dengan cara konversi sebagai berikut :

1. Mencari selisih daya dan persentase selisih tiap-tiap jam dengan beban puncaknya

2. Mencari beban trafo tiap-tiap jam dengan :

$\mathrm{P}_{1,2,3, \ldots}=\mathrm{P}-\left(\mathrm{P} \times \%_{1,2,3, . .}\right)$

Keterangan :

$\mathrm{P}=$ Beban Puncak Trafo

$\mathrm{P}_{1,2,3, \ldots} \quad=$ Beban trafo pada pukul 01:00,02:00,03:00,...

$\%_{1,2,3,}=$ Persentase selisih dengan beban puncak pada pukul 01:00,02:00,03:00,...

Contoh perhitungan menggunakan trafo KU0017 adalah sebagai berikut :

- Selisih pada pukul 01:00

$>$ Selisih $=$ Beban Puncak Penyulang -

Beban Penyulang Pukul 01:00

$=3429821,962-2126051,397$

$$
\begin{aligned}
& =1303771 \mathrm{kVA} \\
= & (\text { Selisih pada pukul 01:00/ } \\
& \text { Beban Puncak Penyulang }) \times 100 \% \\
= & (1303771 / 3429821,962) \times 100 \% \\
= & 38,01 \% \\
= & \mathrm{P}-\left(\mathrm{P} \times \%_{1}\right) \\
= & 47,351-(47,351 \times 38,01 \%) \\
= & 44,886 \mathrm{kVA}
\end{aligned}
$$

Hasil perhitungan diatas menunjukkan penentuan beban trafo KU0017 pada pukul 01:00 adalah 44,886 kVA untuk jam lainnya pada trafo KU0017 dilakukan dengan cara yang sama menghasilkan pola pembebanan yang dapat dilihat pada gambar 5 .

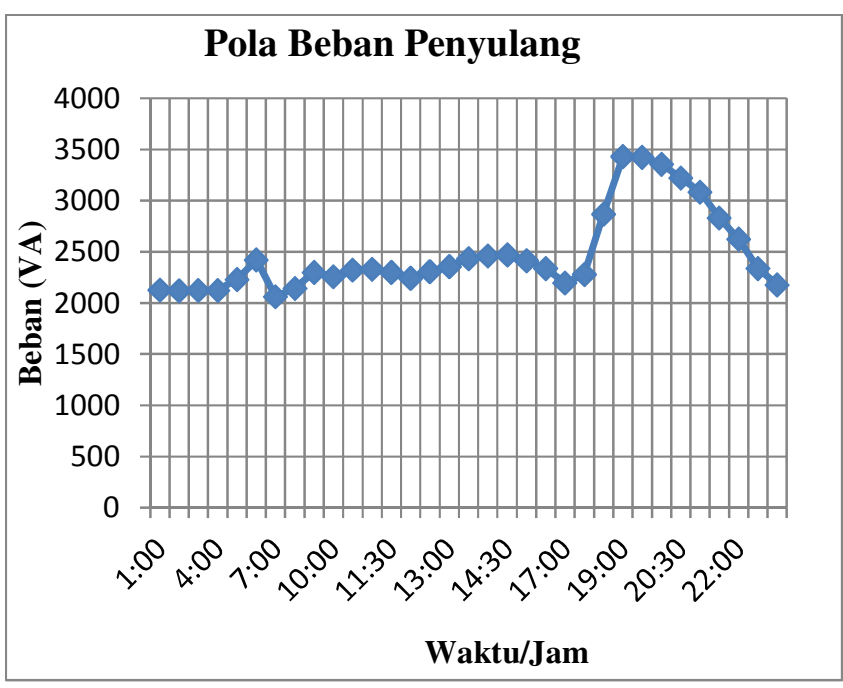

Gambar 5. Pola Beban Harian Penyulang

Dapat dilihat dari pola beban harian penyulang dan pola pembebanan trafo sudah terlihat sama mengikuti pola beban pada gambar diatas. Berikut salah satu contoh pembebanan pada trafo KU0017 pada gambar 6.

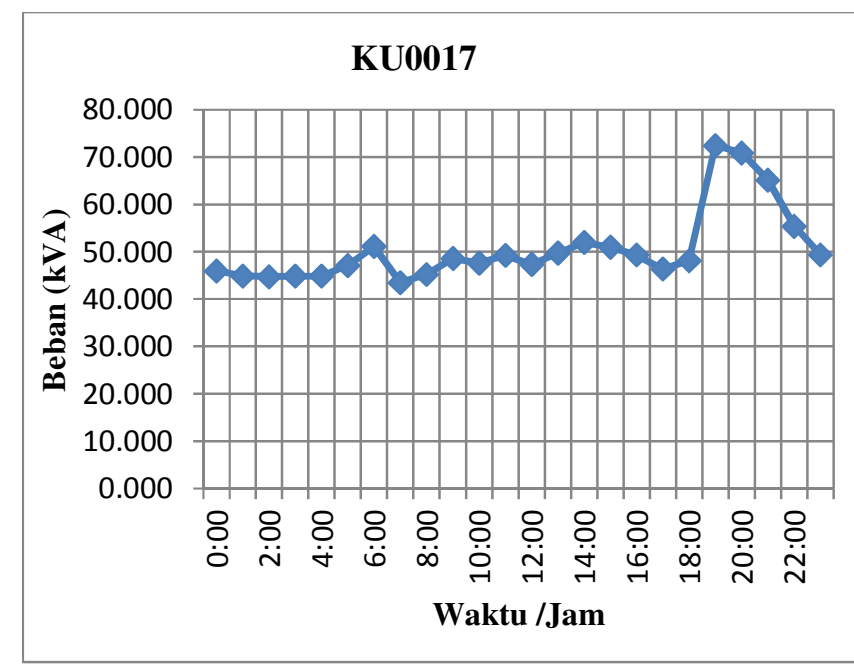

Gambar 6. Grafik Pembebanan Trafo KM0113

Berdasarkan gambar 5 dan 6 dapat dilihat bahwa bentuk kurva pola pembebanan antara beban harian penyulang Abang dengan trafo KU0017 sudah sama. Hasil yang digunakan 
dalam simulasi adalah pada pukul 12:00, karena daya tertinggi yang dihasilkan oleh DG (PLTS) pada pukul 12:00 sebesar $706,101 \mathrm{~kW}$.

\section{B. Profil Tegangan pada Bus Beban Saat Tidak Terhubung $D G$}

Hasil dari salah satu profil beban pada simulasi untuk mengetahui profil tegangan pada bus beban dengan kondisi tidak terhubung DG ditunjukkan pada tabel 1 dan gambar 7.

TABEL I

HASIL SIMULASI TRAFO KU0017

\begin{tabular}{|c|c|c|c|c|c|c|c|}
\hline No & $\begin{array}{c}\text { Bus } \\
\text { Beban }\end{array}$ & Waktu/Jam & 1:00 & $\ldots$ & 12:00 & 19:00 & 24:00 \\
\hline \multirow{3}{*}{1} & \multirow{3}{*}{ KU0017 } & $\begin{array}{l}\text { Beban } \\
\text { (kVA) }\end{array}$ & 44,89 & ...... & 47,35 & 72,41 & 45,95 \\
\hline & & $\begin{array}{l}\text { Profil } \\
\text { Tegangan } \\
\text { (Volt) }\end{array}$ & 348 & $\ldots$ & 330 & 325 & 347 \\
\hline & & $\begin{array}{l}\text { Drop } \\
\text { Tegangan } \\
(\%)\end{array}$ & 8,43 & & 13,23 & 14,48 & 8,65 \\
\hline
\end{tabular}

Dari tabel 1 diatas dapat diketahui bahwa salah satu pembebanan trafo KU0017 pada pukul 12:00 sebesar 47,35 kVA dengan profil tegangan 330 Volt dengan persentase drop tegangan $13,23 \%$.

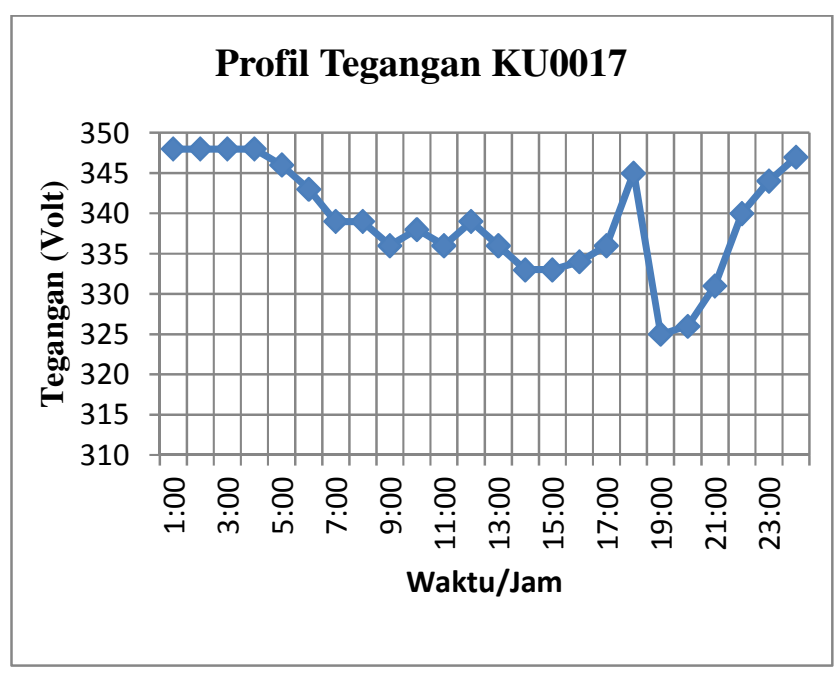

Gambar 7. Grafik Profil Tegangan

Dapat diketahui bahwa profil tegangan pada pukul 12:00 saat tidak beroperasinya PLTS sebesar 330 Volt dengan persentase drop tegangan $13,23 \%$ dan yang ditunjukkan pada panah diatas merupakan profil tegangan saat beban puncak malam pukul 19:00 sebesar 325 Volt dengan persentase drop tegangan $14,48 \%$. Hal ini akan berbanding terbalik pada grafik profil beban bus beban KU0017

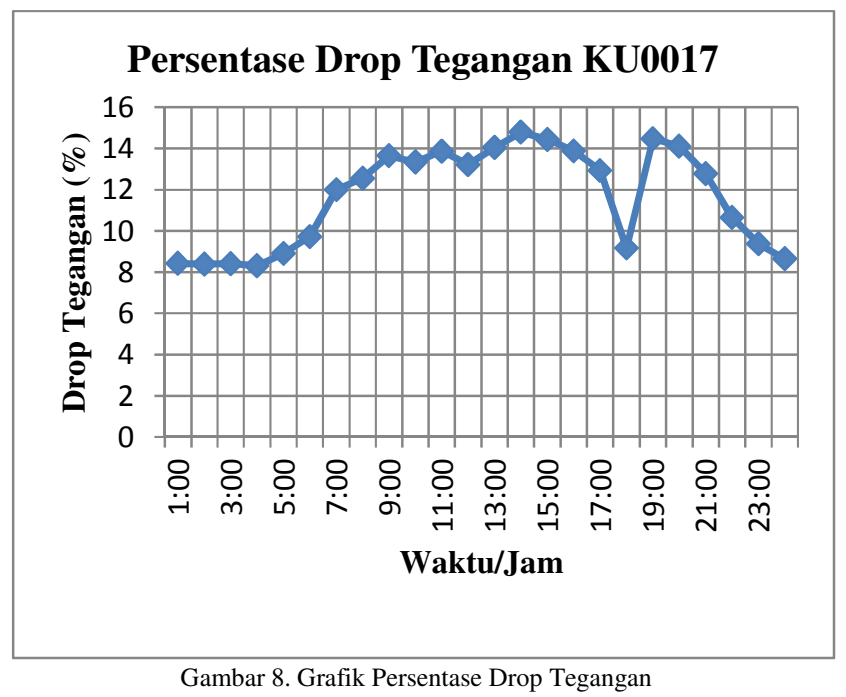

Dapat diketahui besarnya profil tegangan yang terjadi pada Trafo KU0017 pada pukul 12:00 saat tidak beroperasinya PLTS sebesar 330 Volt dengan persentase drop tegangan $13,23 \%$. Profil tegangan saat beban puncak terjadi pada pukul 19:00 sebesar 325 Volt dengan persentase drop tegangan $14,48 \%$. Persentase drop tegangan pada pukul 20:00 - 00:00 mengalami penurunan sesuai dengan grafik diatas. Drop Tegangan pada trafo ini cukup besar dikarenakan letak beban berada cukup jauh dari sumber utama dan tidak beroperasinya DG (PLTS Kubu) .

C. Profil Tegangan pada Bus Beban Saat Terhubung DG

Hasil dari salah satu profil beban pada simulasi untuk mengetahui profil tegangan pada bus beban dengan kondisi terhubung DG ditunjukkan pada tabel 2.

TABEL II

HASIL SIMULASI TRAFO KU0017

\begin{tabular}{|c|c|c|c|c|c|c|c|}
\hline No & $\begin{array}{c}\text { Bus } \\
\text { Beban }\end{array}$ & Waktu/Jam & 1:00 & $\cdots$. & 12:00 & 19:00 & 24:00 \\
\hline \multirow{3}{*}{1} & \multirow{3}{*}{ KU0017 } & $\begin{array}{l}\text { Beban } \\
(k V A)\end{array}$ & 44,89 & & 47,35 & 72,41 & 45,95 \\
\hline & & $\begin{array}{l}\text { Profil } \\
\text { Tegangan } \\
\text { (Volt) }\end{array}$ & 348 & $\ldots$ & 330 & 325 & 347 \\
\hline & & $\begin{array}{l}\text { Drop } \\
\text { Tegangan } \\
(\%)\end{array}$ & 8,43 & $\ldots$. & 13,23 & 14,48 & 8,65 \\
\hline
\end{tabular}

Dari tabel 2 diatas dapat diketahui bahwa salah satu pembebanan trafo KU0017 pada pukul 12:00 sebesar 47,35 $\mathrm{kVA}$ dengan profil tegangan 339 Volt dengan persentase drop tegangan $10,85 \%$. 


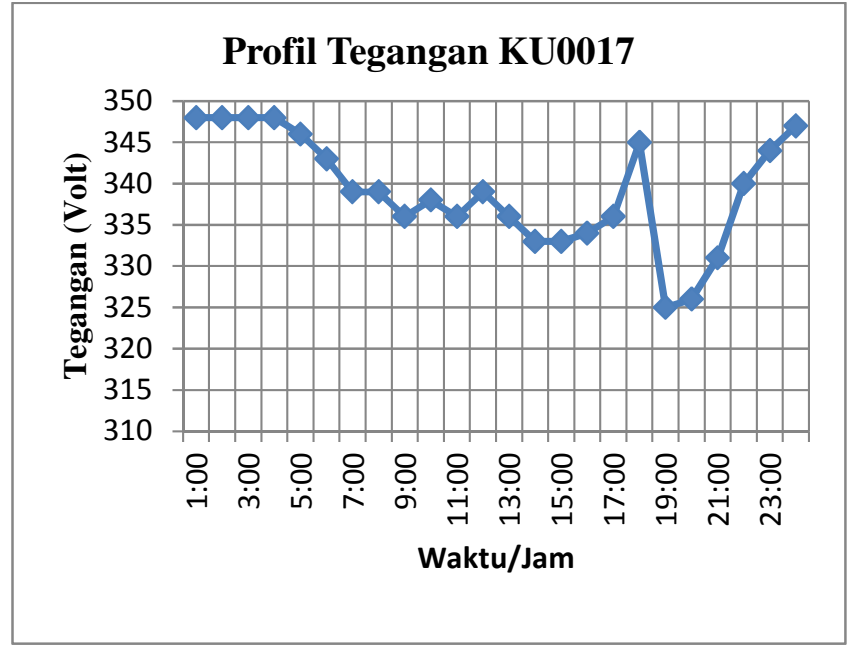

Gambar 9. Grafik Profil Tegangan

Dapat diketahui bahwa profil tegangan pada pukul 12:00 saat PLTS beroperasi sebesar 339 Volt dengan persentase drop tegangan $10,85 \%$ dan yang ditunjukkan tanda panah diatas merupakan profil tegangan saat beban puncak pukul 19:00 yaitu 325 Volt dengan persentase drop tegangan 14,48\% saat PLTS tidak beroperasi. Hal ini akan berbanding terbalik pada grafik profil beban KU0017.

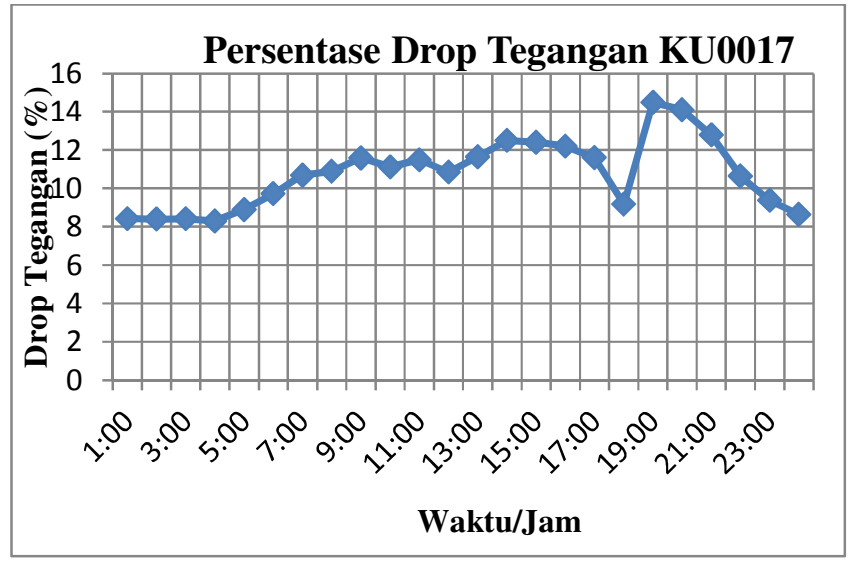

Gambar 10. Grafik Persentase Drop Tegangan

Dapat diketahui profil tegangan pada Trafo KU0017 pada pukul 12:00 saat beroperasinya PLTS sebesar 339 Volt dengan persentase $10,85 \%$ dan saat tidak beroperasinya PLTS sebesar 330 Volt dengan persentase drop 13,23\%. Profil tegangan saat beban puncak pada pukul 19:00 sebesar 325 Volt dengan persentase drop tegangan 14,48\%. Drop Tegangan pada jam 20:00 - 00:00 mengalami penurunan sesuai dengan grafik diatas

\section{Pengaruh Beroperasinya DG Terhadap Drop Tegangan}

Analisis pengaruh beroperasinya DG (PLTS) Kubu terhadap drop tegangan secara keseluruhan dapat dilihat pada tabel 3.

\section{PENGARUH BEROPERASINYA DG TERHADAP DROP TEGANGAN}

\begin{tabular}{|c|c|}
\hline $\begin{array}{c}\text { Waktu / } \\
\text { JAM }\end{array}$ & $\begin{array}{c}\text { Drop } \\
\text { Tegangan } \\
(\boldsymbol{\%})\end{array}$ \\
\hline $7: 00$ & 1,73 \\
\hline $8: 00$ & 2,22 \\
\hline $9: 00$ & 2,72 \\
\hline $10: 00$ & 2,99 \\
\hline $11: 00$ & 3,14 \\
\hline $12: 00$ & 3,17 \\
\hline $13: 00$ & 3,15 \\
\hline $14: 00$ & 3,05 \\
\hline $15: 00$ & 2,67 \\
\hline $16: 00$ & 2,23 \\
\hline $17: 00$ & 1,78 \\
\hline
\end{tabular}

Dari tabel 3 dapat diketahui bahwa dengan beroperasinya DG dari pukul 7:00 sampai pukul 17:00 dapat menurunkan drop tegangan saat pagi hari pukul 8:00 sebesar 2,22\%, saat siang hari pukul 12:00 sebesar 3,17\% dan pada saat sore hari pukul 17:00 sebesar 1,78\%.

\section{E. Rugi-Rugi Daya Pada Penyulang Abang}

Dapat diketahui dengan adanya interkoneksi DG besarnya rugi-rugi daya pada penyulang Abang mengalami penurunan pukul 12:00 sebesar $361,560 \mathrm{~kW}$ turun menjadi $248,575 \mathrm{~kW}$. Dan total rugi-rugi daya secara keseluruhan saat tidak terhubung DG sebesar 6.723,51 kW, saat terhubung DG sebesar 5.699,828 kW. Secara keselurahan dengan adanya interkoneksi DG dapat menurunkan rugi-rugi daya sebesar 1023,682 kW. Di bawah ini merupakan perbandingan rugirugi daya penyulang saat kondisi tidak terhubung DG dan terhubung DG selama 24 jam.

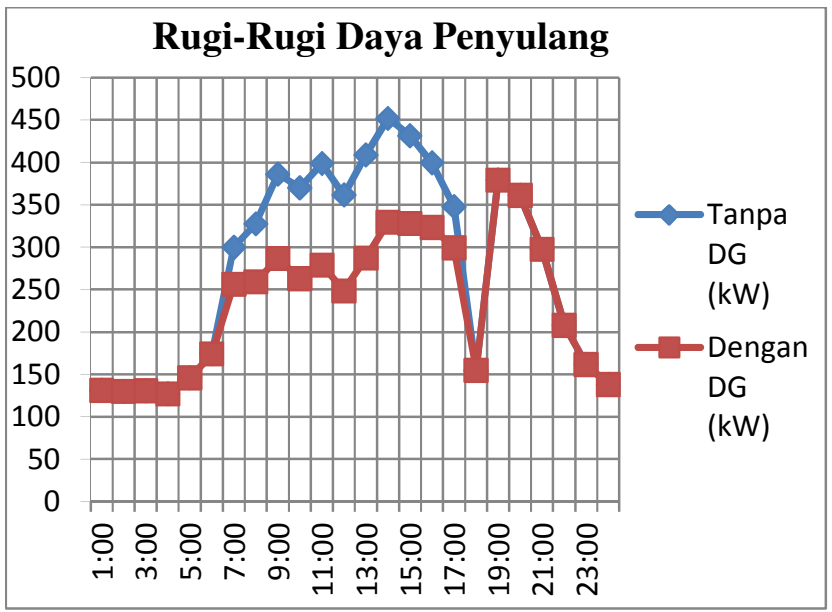

Gambar 11. Grafik Perbandingan Rugi-Rugi Daya Penyulang

TABEL III 


\section{KESIMPULAN}

Berdasarkan hasil analisis pembahasan yang telah dilakukan, maka dapat ditarik simpulan yaitu dari hasil analasis diperoleh persentase drop tegangan saat tidak terhubung DG sebesar 13,23\% dan saat terhubung DG sebesar 10,85\%. Beroperasinya DG dari pukul 7:00 sampai pukul 17:00 dapat menurunkan drop tegangan saat pagi hari pukul 8:00 sebesar 2,22\%, saat siang hari pukul 12:00 sebesar 3,17\% dan pada saat sore hari pukul 17:00 sebesar 1,78\%. Dengan interkoneksi DG pada Penyulang Abang besarnya rugi-rugi daya pada kondisi tidak terhubung dengan DG adalah $6.723,51 \mathrm{~kW}$, turun sebesar 5.699,828 kW setelah penyulang Abang terhubung DG (PLTS Kubu).

\section{REFERENSI}

[1] Bawan., Hadi., Sarjiya. "Dampak Pemasangan Distributed Genartion Terhadap Rugi-Rugi Daya”. Jurnal Ilmiah Foristek. Vol 21 No. 2. 2012

[2] Fitrizawati, Suharyanto, Isnaeni. "Pengaruh Pemasangan Distributed Generation Terhadap Profil Tegangan Pada Jaringan Distribusi". Techno ISSN 1410-8607, Vol. 13 No. 1. 2012.

[3] Gerald. V., Hartati, Rukmi Sari., Weking., A. I. "Analisis Energi Listrik Terselamatkan pada Penyulang Bangli PT.PLN (Persero) Area Bali Timur dengan Beroperasinya PLTS Kayubihi”. Majalah Ilmiah Teknologi Elektro, Vol. 15 No. 1. 2016.

[4] Nusaman. G., I. W. Sukerayasa. Hartati, Rukmi Sari. "Analisa Pengaruh Interkoneksi Distributed Generation (PLTSA Suwung) Terhadap Rugi-Rugi Daya dan Keandalan Pada Penyulang Serangan". Majalah Ilmiah Teknologi Elektro, Vol. 14 No. 2. 2015.

[5] Putra, I. G. N. Dion Adi., Giriantari I. A. D., Ariastina, W. G. "Analisis Rugi Daya Pada Penyulang Bangli dengan Beroperasinya PLTS Kayubihi”. Majalah Ilmiah Teknologi Elektro. Vol. 14 No. 1. 2015

[6] Priatna, N. Abisatya. "Analisa Pengaruh Lokasi Distributed Generation Terhadap Susut Daya dan Keandalan Pada Penyulang Abang di Karangasem". Denpasar, Universitas Udayana Jurusan Teknik Elektro. 2014.

[7] Sunanda, W. "Perbaikan Keandalan Sistem Melalui Pemasangan Distributed Generation”. Jurnal Ilmiah Foristek. Vol. 3 No. 2. 2013

[8] Viawan, F.A. "Steady State Operation and Control of Power Distribution Systems in the Presence of Distributed Generation". Departement of Energy and Environment Chalmers University of Technology. 2008.

[9] Stevenson, W. D., Idris. K (Ed). "Analisa Sistem Tenaga Listrik". Jakarta : Penerbit Erlangga. 1996 